\title{
Comparative Law of Defamation Law Through social media In New York Based on The New York Consolidated Laws and In Indonesia
}

\author{
Freddy Lotasi ${ }^{1}$, Kartina Pakpahan ${ }^{2}$, Elvira Fitriyani Pakpahan ${ }^{3}$, Tommy Leonard ${ }^{4}$, Sonya \\ Airini Batubara ${ }^{5}$ \\ \{lotasi.freddy@gmail.com¹, kartinapakpahan@unprimdn.ac.id ${ }^{2}$, \\ elvirapakpahan@unprimdn.ac.id ${ }^{3}$, tommy-journal.ac.id $\left.{ }^{4}\right\}$ \\ Universitas Prima Indonesia ${ }^{12345}$
}

\begin{abstract}
One of the cases that occurs very often in social media is the case of humiliation or defamation through the social media and Indonesia is one of them. But what about the United States, especially the state of New York, they highly uphold the Freedom of Opinion and Religion as regulated in the first amendments the Bill of Rights (declaration of rights). Which is in New York City, defamation is considered contrary to the First Amandement in the constitution, then in America there is only accountability for compensation. while in Indonesia, defamation gets criminal sanctions and fines in the form of imprisonment and compensation are the main sanctions in cases of defamation in Indonesia, in terms of legal application, the threat of imprisonment is regulated in Article 45 paragraph (3) of Law No. 11 of 2008 concerning Information and Electronic Transactions and the Criminal Code from articles 310 to 321 .
\end{abstract}

Keywords: Defamation, social media, Libel, Slander, Bill of Rights

\section{Introduction}

\subsection{Background}

The rise of cases of defamation through social media in Indonesia, although there is the governing law, the +62 netizens still go too far in expressing their opinions which leads to the defamation. But what about the United States especially New York States, where is known that they highly uphold the Freedom of Expression and Religion which is regulated in the first amendment of the Bill of Rights (declaration of rights). Bill of Rights is the name for the first ten amendments of the United States Constitution.

Is it because the Bill of Rights makes a developed country such as United States not regulate criminal acts of insult or defamation? It turns out that although the United States highly upholds the Bill of Rights, every state including New York city has its own Constitutions which is called as Constitution of the State of New York and it regulates defamation and humiliation where their legal language is Libel and Slander. The existence of legal system differences in Indonesia and New York City, United States becomes a challenge in my research to compare legal position of the perpetrator of the Libel and Slander through social media in New York City and in Indonesia. 


\subsection{Identification of the Problem}

Based on the explanation from the background above, the problems that I will discuss are:

a. How is the law of defamation through social media in New York City?

b. How is the law of defamation through social media in Indonesia?

c. How does the comparation of the application of the defamation through social media in New York City and in Indonesia?

\subsection{The Purpose of the Research}

In addition to the research mentioned above, the author hopes this research can achieve the following benefits:

a. Teoritically :

- As a contribution both to science in general and to law in particular;

- Giving benefits so that it can become a reference for anyone who is in need on the future.

b. Practically:

- Contributing thoughts to the government of the Republic of Indonesia regarding the humiliation and defamation through the social media.

- Provides knowledge and insight for readers or the general public especially in writing itself.

\subsection{The Method of the Research}

In this research, the authors used a Yuriditive Normative or can be called Doctrinal Legal Search. In this normative research, it focuses on positive legal norms in the firm of laws in Indonesia and in New York City, United States or law is also conceptualized as the rules of norms that are benchmarks for human behaviour deemed appropriate. In this normative legal research, the writer conducts research on the principles of law, by identifying in advance the legal principles that have been formulated in regulations.

\subsection{Review of the Research}

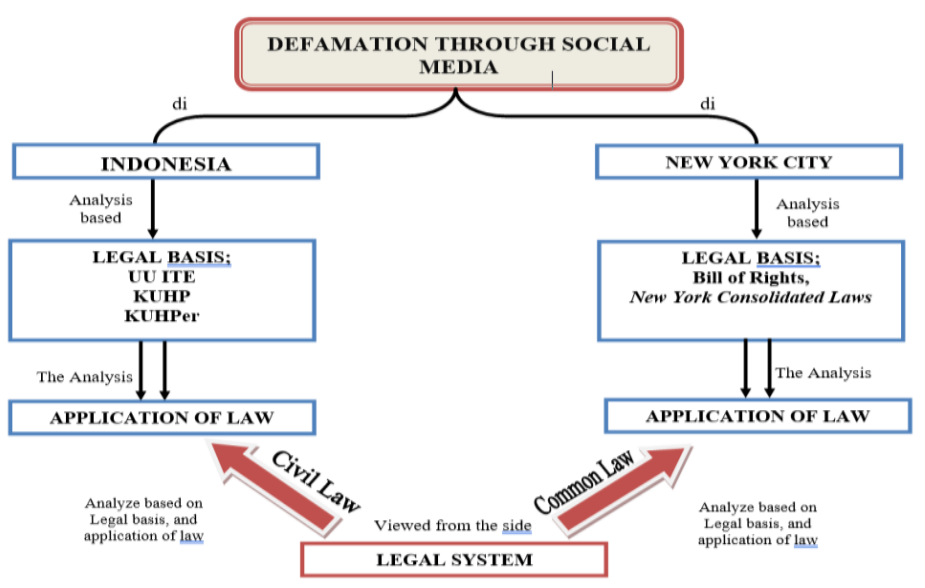




\section{Research Methods}

\subsection{The Regulation of Defamation through Social Media in New York City Defamation in the United States}

New York is a state of the United States which is located in the region between the Middle Atlantic, and the Northeast of the United States. The United States where we all know that they highly uphold the Freedom of Expression and Religion which is regulated in the first amendment to the Bill of Rights (declaration of rights). The Declaration of Rights plays an important role in the law and government of the United States, and is a major symbol of the country's freedom and culture. One of the fourteen copies of the Declaration of Rights is on public display at the National Archives of the United States, Washington, D.C.

The Freedom of expression in the United States is regulated in the Constitutional Law in the First Amendment (Bill of Rights) which reads; "Congress will not pass the laws regulating the state to sponsor religion, or which prohibiting the administration of religious freedom; or restrict the freedom of speech, or freedom of the press; or the rights of the public to assemble peacefully, and submit a petition to the Government to respond to complaints [1]".

In the United States (United States), there are many definitions of defamation or the legal English term is "defamation". This diversity is also influenced by the regulations owned by each state. However, although each state has different definitions of insult, in practice the elements contained in it still have in common. In the United States, there are four sources of law, namely constitutional law, administrative law, statutes (written law in a country), and common law (which includes the case law). The most important source of law is the Constitution of The United States, and everything is under it, and is submit to it. There must be no law that contradicts the Constitution of the United States. For example, if Congress approves a statute that is contrary to the constitution, the Supreme Court may deem the law unconstitutional and invalidate it [2].

The Constitution of the Unites States consists of 27 amendments and the Bill Of Rights is the first amendment to the Constitution of the United States, in which the writing of this scientific papers Bill of Rights will be the basis for the highest hierarchy of regulations in the discussion of defamation through social media in New York City, United States. The federal administrative law of United States includes laws, common law, and directives issued by the Office of Information and Regulation in the Executive Office of the President, which determine together the extent of powers and responsibilities vested in the administrative bodies of the United States government (both executive branch agencies and independent institutions). The executive, legislative, and judicial branches of the US federal government are not always able to directly carry out their constitutional responsibilities. Therefore, special powers are delegated to an institution, council or committee. These administrative governing board oversee and monitor the activities in complex areas, such as commercial aviation, medical device manufacturing, and the securities market.

Based on the quotes from Wikipedia, I can conclude that from a regulatory perspective, the legal sources of the Hierarchy of Regulations in New York, United States that we will use in this discussion are; 


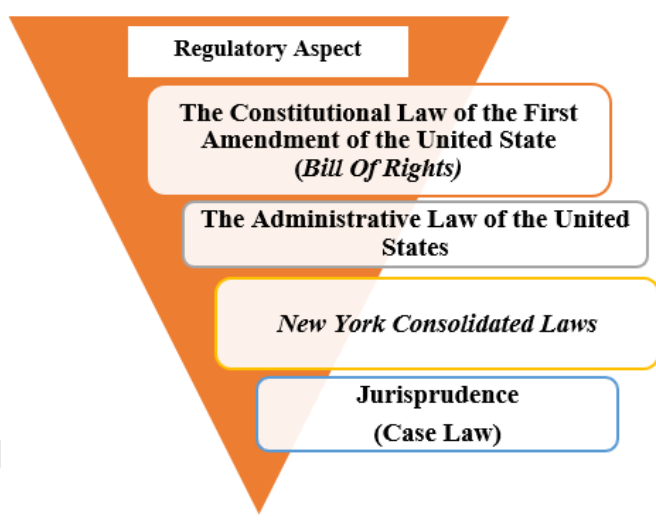

Although the Constitutional Law regulates freedom of expression (Bill of Rights), in the New York statute there are rules governing the defamation of these rules.

\subsection{Defamation in New York}

The rules governing defamation in New York City, Unites States are the New York Consolidated Laws, Civil Rights Law - CVR, Article 7 on Miscellaneous Rights and Immunities § section 78 concerning Mitigating Circumstances in Action for Libel or Slander, which reads; "In an action for libel or slander the defendant may prove mitigating circumstances, including the sources of his information and the grounds for his belief, whether or not he has pleaded or attempted to prove any defense. A defendant in default for want of an answer may prove such mitigating circumstances upon a reference or inquiry to ascertain the amount of the plaintiff's damages. Matter tending only to mitigate or reduce damages is a partial defense and may be set forth in the answer. "

Based on the sound of the rules, it can be concluded that the regulations in New York recognize the existence of written defamation (libel) such as newspapers, other publications, articles, blogs or social media posts, as well as recognize verbal defamation. Sanctions against the perpetrators of defamation are compensation and the defendant has the right to prove a situation that can alleviate the allegations against him, which is the judge's consideration in deciding the amount of compensation. In America, there are many definitions of libel. This diversity is also influenced by the regulations owned by each state.

However, although each state has different definitions of humiliation, in practice the elements contained in it still have similarities [3]. In this case, Rodney A. Smolla in his book entitled "Law of Defamation" explains that, although definitions vary significantly by country, the causes of acts of defamation often include the following elements:

a. statement of fact;

b. it is wrong;

c. and defamatory;

d. from and about the plaintiff;

e. issued to third parties (in written form or real form);

f. that is not a special or conditional requirement;

g. which caused the actual injury (unless avoided in the presence of a suspected hazard);

h. it was the result of a fault by the accused (usually); which causes specific losses (money) in addition to a general (occasional) reputation history [4]. 
In the United States there is no criminal liability for acts of defamation or humiliation. This is considered contrary to the First Amendment in the United States constitution which guarantees freedom of opinion and freedom of the press. This view was expressed by Frederick Schauer, Frank Stanton professor of the First Amendment, John F. Kennedy School of Government, Harvard University during the Law Colloquium event in Jakarta which took place last week [5] The Bill of Rights, freedom of speech and freedom of the press are the main reasons the United States does not provide criminal penalties against the perpetrators of defamation, whether committed in writing or orally, and in the New York state regulations in the New York Consolidated Law, Civil Rights Law - CVR, Article 7 on Miscellaneous Rights and Immunities $\S$ section 78 on Mitigating Circumstances in action for libel or slander, explaining that the defendant or the perpetrator of defamation can provide a defense in court that can reduce the amount of compensation to the plaintiff. Therefore, the threat of sanctions against perpetrators in New York City based on their regulations is a meaningful compensation which is included in civil sanctions not criminal sanctions.

Apart from New York City in the New York Consolidated Laws, Civil Rights Law CVR Article 7 on Miscellaneous Rights and Immunities $\S$ section 78 on Mitigating Circumstances in action for libel or slander, there is also Article 7 regarding Miscellaneous Rights and Immunities $\S$ section 74 regarding Privileges in Action for Libel, section 75 on Defamation by Radio or Television, and section 76 on Action for Libel: Evidence, Separate Verdicts. These sections are in the same article as section 78 where the sections explain more about defamation in contrast to section 78 which describes the threat of punishment for damages and the role of the defamation defendant who can defend against allegations of plaintiff.

\section{Results and Discussion}

\subsection{Regulation of the Law on Defamation through social media in Indonesia Law No. 19 of 2016 on the Amendment to Law No. 11 of 2008 on Electronic Information and Transactions}

In Indonesia, since the existence of Law No. 11 of 2008 on Electronic Information and Transactions Article 27 paragraph (3) which regulates defamation, there are many cases of defamation through social media that emerged after the existence of this Law, which reads:

"Any Person who knowingly and without authority distributes and/or transmits and/or causes to be accessible Electronic Information and/or Electronic Documents with contents of affronts and/or defamation" [6]

The Law in Article 27 paragraph (3) of Law No. 11 of 2008 on Electronic Information and Transactions, in my opinion, it can be described as follows:

a. Everyone. The spreader can become a criminal suspect / defendant if the spreader can be held responsible for the crime. It must be analyzed in depth who is the main spreader of the content.

b. Intentionally and without rights. This element must be proven to whom the disseminator is informing the content and for what purpose. Is the purpose of the content created to personally demonize or to inform suspected criminal activity?

c. Distribute and / or transmit and / or make Electronic Information and / or Electronic Documents accessible. This element is fulfilled if the content can be accessed by various parties and is known to the public. 
d. Those who have a content of insulting and / or defamation. This element should be further criticized and analyzed with the help of a linguist (expert).

Sanctions for violations of Article 27 paragraph (3) of Law No. 11 of 2008 on Electronic Information and Transactions is regulated in Article 45 paragraph (3) of Law No. 11 of 2008 on Electronic Information and Transactions, which reads:

" Any Person who knowingly and without authority distributes and/or transmits and/or causes to be accessible Electronic Information and/or Electronic Documents with contents of affronts and/or defamation as referred to in Article 27 paragraph (3) shall be sentenced to imprisonment not exceeding 4 (four) years and/or a fine not exceeding Rp750.000.000,00 (seven hundred and fifty billion rupiah)" [7]

In Law No. 19 of 2016 on the Amendment to Law No. 11 of 2008 on Electronic Information and Transactions Article 45 paragraph (5) that defamation through social media is strictly explained as a complaint offense, which reads:

" The provision as referred to in paragraph (3) constitutes an offense for complaint" [8]

Essentially a humiliation, defamation is an act of attacking someone's honor or good name, so that that person's good name is tainted or damaged.

Historically, the provisions of Article 27 paragraph (3) of Law no. 11 of 2008 on Electronic Information and Transactions prior to the existence of Law No. 19 of 2016 on Amendments to Law No. 11 of 2008 on Information and Electronic Transactions article 45 paragraph (5) refers to the provisions of humiliation or defamation as regulated in the Criminal Code, in particular Article 310 of Criminal Code and Article 311 of Criminal Code. In the Criminal Code it is strictly regulated that insult is an offense on complaint.

Complaints here must be distinguished from reports. Reports are for notification only. Meanwhile, Complaints are an absolute requirement for prosecution.

\subsection{The Criminal Code}

In the Criminal Code, defamation is spread over several articles, namely:

a. Verbal defamation (Article 310 paragraph (1) of the Criminal Code);

b. Written defamation (Article 310 paragraph (2) of the Criminal Code);

c. Slander (Article 311 of the Criminal Code);

d. Minor humiliation (article 315 of the Criminal Code);

e. False / slanderous complaints (Article 317 of the Criminal Code);

f. False suspicion (Article 318 of the Criminal Code);

g. Humiliation to a person who has died (articles 320-321 of the Criminal Code).

Essentially a humiliation, defamation is an act of harming someone's honor or reputation, so that the reputation is tainted or damaged. In determining the existence of a humiliation or defamation, content and context are very important parts to understand. An intrinsically defiled or damaged person's reputation can only be assessed by that person. In other words, it is the victim who can judge subjectively about the content or which part of the information or electronic document that is deemed to have offended his honor or reputation. The constitution provides protection for the dignity of a person as one of the human rights.

In the Criminal Code, it is strictly regulated that humiliation is a complaint offense. In order to simplify the definition of complaint offenses, it is necessary to describe the general principles in criminal law. In the Criminal Code, matters of a public law nature have been regulated. Therefore, there is a general principle which dictates that: "in order to prosecute an offense, whether in the form of a crime or an offense, the right to prosecution rests with the public prosecutor, and generally the request from the afflicted party to prosecute has no effect". This means that the presence or absence of a request from the victim or the victim's 
family has no effect on the prosecution. Even so, the Criminal Code recognizes exceptions or deviations from the general principles of criminal law, namely: in the provisions of the Criminal Code there are several types of offenses that can only be prosecuted if there is a complaint from the sufferer (the victim). And, this kind of offense is classified as a complaint offense. For the crime of defamation or insulting or all of the insults regulated in Article 310 to Article 321 of the Criminal Code, this is a complaint offense, with the exception of Article 316 of the Criminal Code, which is an insult committed against a civil servant who is carrying out his legitimate duties. Prosecution for Article 316 does not require complaints from the insulted person (not complaint offense).

In addition, what needs to be considered is the expiration period of a criminal defamation complaint. In Law No. 11 of 2008 on Electronic Information and Transactions itself does not have expired provisions in either filing a complaint or reporting a criminal act, therefore it is necessary to look at the provisions in the Criminal Code. This criminal act of humiliation can only be prosecuted on the complaint of an insulted person, which is a concrete barrier to prosecution, but it is precisely this subjective feeling of the victim that may raise doubts for cowards, prosecutors, or case breakers, whether there is true insult or not [9].

Since the articles of defamation constitute an offense on complaints, the expiration of the complaint is regulated in article 74 of the Criminal Code, which reads; "Complaints may only be submitted within six months after the person entitled to complain knows about the act committed, if he resides in the country of Indonesia, or within nine months after knowing it, if residing outside the country of Indonesia. If at the time a person who is convicted of a crime, has the right to complain not yet the due date as mentioned in the first paragraph, then from then on, he has the right to complain as long as he has missed the time mentioned above [10]. Based on the description of the sound in article 74 of the Criminal Code, it can be concluded that the period of time to complain or report a criminal act of defamation is 6 (six) months if residing in Indonesia, while for those who live outside Indonesia is 9 (nine) months.

\subsection{Comparison of the Application of Defamation Law through social media in New York City and in Indonesia}

\subsubsection{Comparison of Legal Application from a Legal System Aspect}

In the previous subtitles we have discussed the regulation of defamation law through social media in New York City, and we already know the hierarchy of rules we use in discussing this research when viewed from a regulatory perspective, starting from Freedom of speech in the United States is regulated in the first amendment of Constitutional Law (Bill of Rights), Administrative Law of the United States, Constitutional Law of New York City, and Jurisprudence. If viewed from the perspective of the application of the law, we must also look at the legal system of Unites States which uses the Common Law (Anglo Saxon) legal system, which is a legal system based on jurispudence as a source of law. A legal system that prioritizes customary law, a law that runs dynamically in line with the dynamics of society.

Common Law developed in Anglo-Saxon countries, such as England and its colonial countries, such as America, Australia, India, Pakistan, Malaysia, and so on.

The characteristics of the Common Law (Anglo Saxon) legal system are as follows;

a. Jurisprudence as the eye of law, referring to the opinion given by Mahadi, jurisprudence itself is a series of decisions made by judges whose decisions are of the same sound and on similar issues. According to common law adherent country, placing statute as the main source of law is a dangerous thing, this is due to an assumption by them that laws 
are the work of theorists which are very different from reality and are not in sync with existing needs.

b. Adherence to the Doctrine of Stare Decisis / Precedent System, as previously explained, the purpose of the doctrine of stare decisis is a principle that requires judges to follow predetermined precedents. However, even though the common law legal system applies the doctrine of stare decisis, it does not mean that irregularities are not possible by the court. With the application of distinguishing, namely when a court can prove that the facts faced are different from the facts previously decided, then a different decision can be made by the court.

c. Adversary System in judicial proceedings, in the common law countries, the trial process is carried out by means of an examination system that places the two in opposite to each other positions. The two of them disputed each other in front of the judge using their respective lawyers. In the trial, the judge is in a position that does not take sides between the two parties or is neutral in nature [11].

Therefore, if we look at it from the perspective of the application of the law using the Common Law system, so that the hierarchy of sources of law in New York City United States, what we use is;

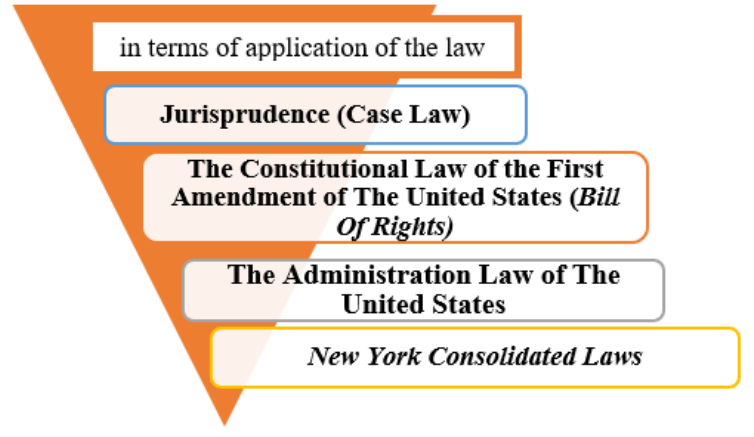

In contrast to New York City which is a state of the United States which uses the Common Law system and Jurisprudence is their main source of law in the application of their law. Meanwhile, Indonesia uses the Civil Law system, which places a written constitution at the highest in the hierarchy of laws and regulations followed by other laws and regulations under it. Because Indonesia adheres to a Civil law system, the application of the law must be in accordance with what is stipulated in Article 27 paragraph (3) of Law No. 11 of 2008 on electronic information and Transactions and also in the Criminal Code, which previously regulations regarding defamation have been described in the previous sub-title, and we will focus on the application of the law.

The characteristics of the Civil Law (European Kontinetal) legal system are as follows; a. The Codification System;

The reason why the Civil Law system adheres to codification is partly because of the political interests of the Roman Empire, in addition to other interests outside of it. Codification is needed to create uniformity of law within and in the midst of legal diversity. In order for customs that have been established as king's regulations to become generally applicable laws, it is necessary to think about a definite legal entity. That thought, the solution is the need for a codification of law. 
b. Judges are not bound by precedent;

Nurul quoted the opinion of Paul Scholten who said that the purpose of organizing the Dutch state organs was about the separation between powers to make laws, judicial power and the cassation system and executive power, and it was not possible for one power interferes with the other, in this way it was formed the jurisprudence.

c. The Judiciary Adheres to the Inquisitorial System

In this system, judges have a big role in directing and deciding a case. Judges are active in finding legal facts and careful in evaluating evidence [12].

Judges in the Civil Law system try to get a complete picture of the events they have faced from the start. This system relies on the professionalism and honesty of judges. Therefore, if viewed from the perspective of the application of the law using the Civil Law system, so that the hierarchy of sources of Indonesian regulatory law, which we use is;

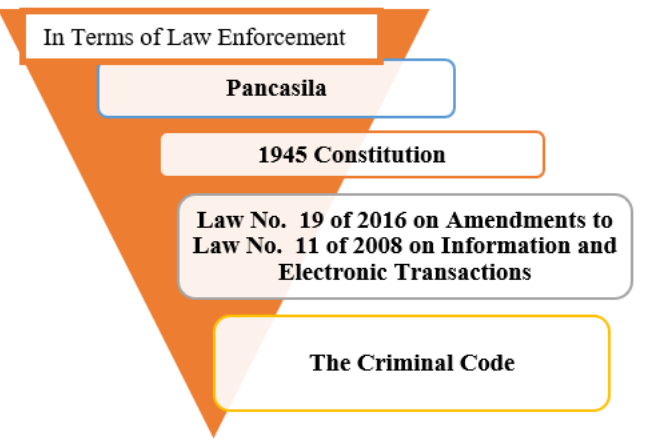

\begin{tabular}{|l|l|l|}
\hline \multicolumn{2}{|c|}{ Difference } \\
\hline No. & Civil Law & Common Law \\
\hline 1 & $\begin{array}{l}\text { The Principle of Legality take } \\
\text { Precedence }\end{array}$ & There is no Principle of Legality \\
\hline 2 & Codified & Not Codified \\
\hline 3 & Based on the Written Law & Based on the Jurisprudence \\
\hline 4 & Does not use a Jury & Use a Jury \\
\hline 5 & $\begin{array}{l}\text { Not Bound by the Previous Judge's } \\
\text { Decision }\end{array}$ & $\begin{array}{l}\text { Bound by the Previous Judge's } \\
\text { Decision }\end{array}$ \\
\hline
\end{tabular}

\subsubsection{Comparison of Legal Application from a Regulatory Aspect}

In the previous chapter we already know the New York regulations governing the defamation, the regulation does not explain in detail about the elements that are included in defamation, therefore the advantages of the common law system are legal certainty because it is based on jurisprudence and defamation cases that have existed, the experts and practicing lawyers in the United States can also interpret the elements of defamation.

The definition of New York defamation: A false statement published or known to a third party - intentionally or negligently - without the knowledge or consent of the subject. In general, statements that are intended to be damaging and humiliate are considered defamatory [13]. Defamation is the publication or communication of a false statement of facts about a person to a third party, which causes damage to the reputation of the people or constitutes 
defamation, without the privileges or consent of the subject persons. Defamation is a very specific claim. Not all statements made, even some that tarnish the reputation of others, are defamation [14].

Defamation occurs when someone makes a false statement to a third party about your character that makes you suffer. Defamation includes libel and slander defamation. Defamation in writing (libel) is the act of defaming another person through writing, such as newspapers, other publications, articles, blogs or social media posts. Slander is the act of making false verbal statements about another person's character or professional position.

The four elements of defamation are:

a. The accused made a written libel and a verbal defamation statement (slander);

b. Regarding the plaintiff;

c. It was issued without any privileges or authorization to others by the defendant; and

d. There is a loss resulting, unless the statement is included in the category "per se" [15].

In the case of defamation, the plaintiff does not need to prove damages. The categories of defamation in New York are:

a. Accusing the plaintiff with a serious crime;

b. Stating false facts that tend to be detrimental to the plaintiff in his business, commerce or profession;

c. Demand that the plaintiff has a disgusting disease;

d. Accused that the plaintiff was impure [16].

Under New York law, the elements of the defamation claim are:

a. A false statement;

b. Issued to a third party without rights or authorization;

c. With the least error due to negligence;

d. Which causes loss of defamation "per se" [17].

So, it can be said that the elements of defamation in New York are someone who makes a false statement that is published or published to a third party without the knowledge of the defamed person, is intentionally defamatory or negligence intended to damage and embarrass the reputation of the defamed person and cause harm to the plaintiff.

Defamation is considered contrary to the First Amandement in the constitution which guarantees freedom of speech and freedom of the press, so in America there is no known criminal liability for acts of defamation or humiliation. This view was expressed by Frederick Schauer, Frank Stanton Professor of the First Amendment, John F.Kennedy School of Government, Harvard University at the Law Colloquium event in Jakarta. In addition, in assessing a case of humiliation the American Supreme Court looks at "who" people which is insulted or defamed and also on the "load or content". What is meant by "who" in this case is related to the social status of a person.

Whether the person is a public figure or not. If a person is a public figure, he must be able to prove conclusively and clearly that what is said to him is factually wrong and has ignored the distance between truth and falsehood. For someone who is not a public figure, he is sufficient to prove that the statements directed against him are not true. Meanwhile, the load/content referred to in this case is whether what is conveyed in the statement contains the public interest or not [18].

Defamation "per se" is a certain statement deemed so injurious that it can be suspected of damaging the person's reputation. New York has four categories of defamation statements, including statements that prosecute someone of a "serious crime," and statements that are 
likely to injure someone in their business, commerce, or profession [19]. Generally, in New York City there is a category of defamation "per se" which includes serious crimes in which a defendant tends to defame someone in his business, commerce, or profession so as to damage that person's reputation, and which is usually included in the "per se se "it is certain that he will be sentenced to pay compensation as a result of his actions.

The first step in evaluating whether a statement is defamation is to examine the contents of the statement itself. Opinions (eg, "In my opinion, this restaurant has food that tastes bad.") That is not a fact, but is usually not a defamatory either. Most of the opinions are speech protected by the First Amendment of the United States Constitution. (Defamation is based on the law of the state, which was defeated, or "preceded", by the United States Constitution.) [20]. Therefore, the application of the New York Law, it still highly upholds freedom of opinion as stipulated in the First Amendment to the United States Constitution (Bill of Rights), which is regulated in the New York state constitution is a defamation statement that slanders and wrong that can damage someone reputation, if that statement is true, is not defamation.

Truth is the absolute defense against defamation. In other words, the creator cannot be held accountable for telling things that are actually true. The party submitting the defense bears the burden of demonstrating the truth of the statement. Generally, compensation for defamation claims is proportional to the losses suffered by the plaintiff. Three types of compensation for defamation claims are damage compensation, nominal compensation, and deterrent compensation [21]. Damage compensation is provided to compensate for the actual loss resulting from the defamation of the defendant. Some of the actual types of harm include damage to the claimant's reputation and position in the community of the plaintiff, personal humiliation, mental suffering and suffering, loss of employment opportunities, and costs of trying to reduce the harm from defamation of the defendant. There are two types of damages (1) special damages and (2) general damages [22].

Specific damages are based on economic loss where there is loss or injury to the property, business, work or profession of the claimant. In order to claim specific damages, the specific economic loss amount must be identified. General damage is for other damages that are not included in special damage. General compensation amounts can be hard to judge and judges in generally have discretion to determine the amount of the award after considering all the facts. In a claim for nominal damages for defamation "per se", the plaintiff may be able to recover nominal damages although the plaintiff does not show actual injury resulting from defamation "per se". Nominal damage is a small monetary reward to prove the plaintiff's reputation [23].

Plaintiffs can seek deterrent compensation in defamation claims. Compensation sentences are intended to punish the accused and prevent the defendant from repeating the defamation. The amount of compensation depends on several factors, such as the level of the accused's malice or malice or intentional behavior [24]. Compensation according to losses suffered is the main sanction in cases of defamation both in New York and by law enforcement it turns out that compensation has 3 types of compensation, namely;

a. Damage compensation is a category of compensation in which the defendant compensates for losses resulting from the defamation, such as; damage to reputation, loss of employment, losses to businesses, professions and also professions.

b. Nominal compensation is compensation which is a small money reward to improve the plaintiff's reputation.

c. Compensation for deterrent effect, is compensation intended to punish and prevent the defendant from repeating acts that defame a good name, and the amount of compensation is seen from the factor of the accused's intention to commit such defamation. 
In the application of Indonesian law which uses the Civil Law legal system, which becomes the legal basis and legal consideration for applying sanctions to the perpetrators of defamation, among others are Article 310 of the Criminal Code and Article 27 paragraph (3) of Law No. 11 of 2008 on Electronic Information and Transactions, and article 45 paragraph (1) of Law no. 11 of 2008 on Electronic Information and Transactions, which sound elements are as follows;

a. Article 310 paragraph (1) of the Criminal Code which explains that a person who commits verbal defamation shall be sentenced to imprisonment not exceeding 9 (nine) months and/or a fine not exceeding Rp. 4,500, - (four thousand and five hundred rupiah), with the following elements:

- Whoever deliberately.

- Attacking someone's honor or reputation.

- By accusing something so that it is publicly known.

b. Article 310 paragraph (2) of the Criminal Code which explains that someone who has committed defamation in writing shall be sentenced to imprisonment not exceeding 1.4 years (one year and four months) months or a fine not exceeding Rp. 4,500, - (four thousand and five hundred rupiah), with the following elements:

- Whoever deliberately.

- Attacking someone's honor or reputation.

- With writing or pictures broadcast, shown or posted in public.

c. Article 27 paragraph 3 of Law no. 11 of 2008 on Electronic Information and Transactions, with elements of criminal acts as follows:

- $\quad$ everyone,

- knowingly and without right,

- distribute and / or transmit and / or make accessible electronic information and / or electronic documents, and

- has a content of insulting and / or defamation.

d. Article 45 paragraph (1) of Law No. 11 of 2008 on Electronic Information and Transactions: Every person who fulfills the elements referred to in article 27 paragraph (1), paragraph (2), paragraph (3), or paragraph (4) shall be sentenced to imprisonment not exceeding 6 (six) months. and / or a fine not exceeding Rp. 1,000,000,000.00 (one billion rupiah).

Defamation law regulations provide legal protection to victims, and not to others. Other people cannot judge the same as the victim's judgment. Meanwhile, context plays a role in providing objective value to content. Understanding the context includes a description of the mood of the victim and the perpetrator, the intent and purpose of the perpetrator in disseminating information, and the interests involved in disseminating content.

Therefore, understanding the context may require the opinion of experts, such as linguists, psychologists, and communication experts. Historically the provisions of Article 27 paragraph (3) of Law no. 11 of 2008 on Electronic Information and Transactions refers to the provisions of defamation or defamation stipulated in the Criminal Code, in particular Article 310 and Article 311 of the Criminal Code. 


\section{Conclusion}

The Constitutional Law of the United States regulates freedom of expression (Bill of Rights), but in the Consolidated Law of New York there are rules governing defamation. These rules are as follows; New York Consolidated Laws, Civil Rights Law - CVR, Article 7 on Miscellaneous Rights and Immunities $\S$ section 78 on Mitigating Circumstances in Action for Libel or Slander; New York Consolidated Laws, Civil Rights Law - CVR Article 7 on Miscellaneous Rights and Immunities $\S$ section 74 on Privileges in Action for Libel; New York Consolidated Laws, Civil Rights Law - CVR Article 7 on Miscellaneous Rights and Immunities $\S$ section 75 on Defamation by Radio or Television.; New York Consolidated Laws, Civil Rights Law - CVR Article 7 on Miscellaneous Rights and Immunities $§$ section 76 on Action for Libel: Evidence, Separate Verdicts; New York Consolidated Laws, Public Service - PBS Article 11 on Provisions Relating to Cable $\S$ section 230 on Liability for Obscenity, Defamation and Invasion of Privacy; New York Consolidated Laws New York Consolidated Laws, Civil Practice Law and Rules - CVP § section 215 on Actions to be Commenced Within One Year: Against Sheriff, Coroner or Constable; for Escape of Prisoner; for Assault, Battery, false Imprisonment, Malicious Prosecution, Libel or Slander; for Violation of Right of Privacy; for Penalty Given to Informer; on Arbitration Award.

The United States uses the Common Law (Anglo Saxon) legal system which is a legal system based on jurisprudence as a source of law. A legal system that prioritizes customary law, a law that runs dynamically in line with the dynamics of society. Although there are regulations that explain about defamation, in practice New York Law still highly upholds the freedom of expression as stipulated in the First Amendment to the United States Constitution (Bill of Rights), which is regulated in the constitutional rules of the state of New York is a defamation statement which is defamatory and wrong that can damage someone's reputation, if the statement is true, is not defamation.

Defamation is considered contrary to the First Amandement in the constitution which guarantees the freedom of opinion and freedom of the press, so in America there is no known criminal liability for acts of defamation or humiliation, only liability for damages. Compensation according to losses suffered is the main sanction in cases of pollution both in New York and by law enforcement it turns out that compensation has 3 types of compensation, namely;

- Damage compensation is a category of compensation in which the defendant compensates for losses resulting from the defamation, such as; damage to reputation, loss of employment, losses to businesses, professions and professions.

- Nominal compensation is compensation which is a small money reward to improve the plaintiff's good name.

- Compensation for deterrent effect, is compensation intended to punish and prevent the defendant from repeating a defamation act, and the amount of compensation is seen from the factor of the defendant's intention to commit such defamation.

Penalties for perpetrators of defamation through social media in Indonesia are imprisonment and fines which shall be sentence to imprisonment noe exceeding 4 (four) years and a fine not exceeding Rp. 750,000,000.00 (seven hundred and fifty million rupiah) which is regulated in Article 27 paragraph (3) of Law no. 11 of 2008 on Electronic Information and Transactions, and article 45 paragraph (1) of Law no. 11 of 2008 on Electronic Information and Transactions. 
The comparison of Defamation Law through social media in New York based on the New York Consolidated Law and in Indonesia, is as follows;

\begin{tabular}{|c|c|c|}
\hline \multicolumn{3}{|c|}{ Differences between Defamation through social media in New York City and in Indonesia } \\
\hline \multirow[t]{2}{*}{ Events } & Indonesia & New York City \\
\hline & $\begin{array}{l}\text { Civil Law: } \\
\text { 1. Codified } \\
\text { 2. Based on Written Law } \\
\text { 3. Does not use a Jury } \\
\text { 4. Not bound by the previous } \\
\text { Judge's decision }\end{array}$ & $\begin{array}{l}\text { Common Law: } \\
\text { 1. Not Codified } \\
\text { 2. Based on Jurisprudence } \\
\text { 3. Use a Jury } \\
\text { 4. Bound by the previous Judge's } \\
\text { decision }\end{array}$ \\
\hline Source of Law & $\begin{array}{l}\text { 1. Law No. 19 of } 2016 \text { on } \\
\text { Amendments to Law No. } 11 \\
\text { of } 2008 \text { on electronic } \\
\text { Information and Transactions. } \\
\text { 2. The Criminal Code } \\
\text { 3. Jurisprudence }\end{array}$ & $\begin{array}{l}\text { 1. Jurisprudence } \\
\text { 2. Bill of Rights } \\
\text { 3. New York Consolidated Laws }\end{array}$ \\
\hline $\begin{array}{l}\text { Elements of } \\
\text { Defamation through } \\
\text { social media }\end{array}$ & $\begin{array}{l}\text { 1. Everyone, } \\
\text { 2. Knowingly and without rights, } \\
\text { 3. Make accessible electronic } \\
\text { information and / or electronic } \\
\text { documents, and } \\
\text { 4. Has a content of insulting and / } \\
\text { or defamation? }\end{array}$ & $\begin{array}{l}\text { 1. A false statement, } \\
\text { 2. Issued or declared without rights } \\
\text { or authority to third parties, } \\
\text { 3. Least error due to negligence, } \\
\text { 4. There was a loss as a result of the } \\
\text { false statement. }\end{array}$ \\
\hline Penalty & $\begin{array}{l}\text { Principal Punishment: } \\
\text { 1. Imprisonment } \\
\text { 2. Fines }\end{array}$ & $\begin{array}{ll}\text { Damages Punishment: } \\
\text { 1. } & \text { Nominal Damages } \\
\text { 2. } & \text { Compensation Damages } \\
\text { 3. } & \text { Deterrent Damages }\end{array}$ \\
\hline
\end{tabular}

\section{Suggestion}

Humiliation and / or defamation is basically a limitation on the rights to freedom of expression. This limitation is basically possible as long as it is not applied to the delivery of expressions that is legally carried out. New York City does not impose criminal sanctions on acts of defamation, but they make it their sanction and regulate regulations that they do not prohibit opinions and state statements that are true, if they make false statements and harm others it is considered defamation that can be demanded compensation.

The regulation of defamation in the realm of criminal law in Indonesia needs to be reconsidered. This is because the purpose of criminal law is to regulate public and state interests which focus on imposing sanctions on perpetrators. While the act of defamation is more of a personal problem that leads to an apology and compensation for material and / or immaterial damages, it can be reconsidered to place the regulation of defamation in the realm of civil law. Defamation articles are often used to attack certain parties, so it is important to be considered in the formation of a defamation law in Indonesia. The purpose of the formation of this Law is to regulate in depth the elements of defamation so that it can be easily understood 
and understood by the public and law enforcement officials in Indonesia so that there is no ambivalence towards acts of defamation in the reality of people's lives.

\section{References}

[1] WirjonoProjodikoro, “Tindak-TindakPidanaTertentu Di Indonesia”, PT RefikaAditama, Bandung, 2010.

[2] Nurul Qamar "PerbandinganSistem Hukum dan Peradilan Civil Law System dan Common Law System", Pustaka Refleksi, Makasar, 2010.

[3] Wikipedia, "Deklarasihak-hak", $2020<$ https://id.wikipedia.org/wiki/Deklarasi_Hak-Hak>, [17 Desember 2019].

[4] Wikipedia, "Hukum Amerika Serikat", <https://id.wikipedia.org/wiki/Hukum_Amerika_Serikat>, [08/08/2020].

[5] Wikipedia, "Konstitusi Amerika Serikd <https://id.wikipedia.org/wiki/Konstitusi_Amerika_Serikat>, [08/08/2020].

[6] Hukum Konstitusi Amerika SerikatAmendemenPeratama (Bill of Rights)

[7] Hukum Konsilidasi New York (New York Consolidated Laws)

[8] Kitab Undang-Undang Hukum Pidana (KUHP),

[9] Kitab Undang - Undang Hukum Perdata (KUHPer),

[10] Undang-Undang No. 11 Tahun 2008 tentangInformasi dan TransaksiElektronik,

[11] Undang-Undang No. 19 Tahun 2019 tentangPerubahanatasUndang-Undang No. 11 Tahun 2008 tentangInformasi dan TransaksiElektronik. 